Article

\title{
Efficiency Improvement of a Photovoltaic Thermal (PVT) System Using Nanofluids
}

\author{
Joo Hee Lee, Seong Geon Hwang and Gwi Hyun Lee * \\ Department of Biosystems Engineering, Kangwon National University, Chuncheon 200-701, Korea \\ * Correspondence: ghlee@kangwon.ac.kr; Tel.: +82-33-250-6495
}

Received: 29 June 2019; Accepted: 6 August 2019; Published: 9 August 2019

\begin{abstract}
Many studies and considerable international efforts have gone into reducing greenhouse gas emissions. This study was carried out to improve the efficiency of flat-plate photovoltaic thermal (PVT) systems, which use solar energy to produce heat and electricity simultaneously. An efficiency analysis was performed with various flow rates of water as the working fluid. The flow rate, which affects the performance of the PVT system, showed the highest efficiency at $3 \mathrm{~L} / \mathrm{min}$ compared with 1 , 2 , and $4 \mathrm{~L} / \mathrm{min}$. Additionally, the effects of nanofluids $\left(\mathrm{CuO} /\right.$ water, $\mathrm{Al}_{2} \mathrm{O}_{3} /$ water $)$ and water as working fluids on the efficiency of the PVT system were investigated. The results showed that the thermal and electrical efficiencies of the PVT system using $\mathrm{CuO} /$ water as a nanofluid were increased by $21.30 \%$ and $0.07 \%$ compared to the water-based system, respectively. However, the increase in electrical efficiency was not significant because this increase may be due to measurement errors. The PVT system using $\mathrm{Al}_{2} \mathrm{O}_{3}$ /water as a nanofluid improved the thermal efficiency by $15.14 \%$, but there was no difference in the electrical efficiency between water and $\mathrm{Al}_{2} \mathrm{O}_{3} /$ water-based systems.
\end{abstract}

Keywords: PVT system; flow rate; nanofluids; efficiency

\section{Introduction}

Solar energy is a renewable and clean energy, and the demand for solar power has increased worldwide because of the need to reduce greenhouse gas emissions [1]. Solar power generation through solar cells, however, has low energy conversion efficiency, and electrical efficiency is reduced as a result of electric performance due to the increase of the cell's temperature [2]. As an alternative, a photovoltaic thermal (PVT) system combined with a photovoltaic (PV) module and a solar thermal collector has been proposed, which circulates the fluid to lower the temperature of the PV cell and produces heat and electricity simultaneously [3]. Combining the two systems has the advantage of reducing the installation area compared to separately installing the PV module and the solar thermal collector [4]. Since the 1970s, a considerable number of studies on PVT technology have been conducted, and many international developments have emerged from these studies [5].

Tripanagnostopoulos et al. [6] constructed a hybrid PVT system and carried out a study using air as a circulating medium, based on two types of the PV modules. The results showed that the total efficiency of this system can be improved through the circulation medium. Aste et al. [7] compared the daily and annual energy yields of the standard PV module and the PVT collector. This suggested that although the electricity production of the PVT system is slightly lower than that of the standard PV module, PVT technology has a high overall efficiency due to producing thermal energy at the same time. Prakash [8] conducted a transient analysis of the PVT collector by spilling water/air under a solar cell, and reported the thermal efficiency of air as the heating medium. Chow et al. [9] evaluated PVT collectors from a thermodynamic point of view, depending on the presence or absence of a glass cover above the PV module. They reported that the glazed PVT system was more suitable for maximizing the total energy output. A CPV (concentrated photovoltaic) system is also useful for utilizing solar 
energy, but it is important to include an appropriate cooling system for the effective operation of the $\mathrm{CPV}$ system, because it increases the operating temperature of the solar cell and reduces the electrical efficiency, in turn decreasing the lifetime of the solar cell [10]. Sharaf et al. [11] defined the CPVT (concentrated photovoltaic thermal) as a hybrid system of a CPV and PVT, which concentrates solar radiation and converts it into useful electric and thermal energy. CPVT collectors have been reported to increase the intensity of solar radiation using concentrator optics, unlike conventional PVT collectors. Coventry [12] showed that the heat loss of the CPVT does not increase as the operating temperature increases, due to a decrease in surface area. However, the CPVT is more costly than the flat-plate PVT module because of the additional expense of high-efficiency solar cells for large scale electricity production, solar tracking drive, etc. [13].

The overall performance of the PVT system is affected by many factors relating to the collection of heat and electrical energy [14]. The key to designing a solar collector's cooling system is to control the flow rate of the working fluid, which can directly affect the operating temperature and the performance of the system in terms of the overall power output [15]. Bambrook and Sproul [16] changed the mass flow rate of air through the PVT system, confirming an increase of the thermal and electrical efficiencies, with an increasing flow rate. Na et al. [17] analyzed the performance of the conical solar concentrator system according to the mass flow rate of the working fluid. The results showed that thermal efficiency tends to improve with an increasing flow rate, but decreases when the optimum flow rate is exceeded.

Most solar systems use working fluids such as water, air, and ethylene glycol. Because these working fluids have low thermal conductivity, the maximum efficiency that can be obtained in existing systems is limited. Therefore, an efficiency improvement of the solar system is needed via an increase of the heat transfer characteristics of the working fluid. Nanofluids, which can be used as the working fluid (and which have exceptional heat transfer characteristics) were presented by Choi and Eastman [18]. These nanofluids have nanoscale particles, which were distributed in base fluids such as water and ethylene glycol. Lee et al. [19] manufactured oxide nanofluids, which have improved thermal conductivity while containing small amounts of nanoparticles $\left(\mathrm{CuO}, \mathrm{Al}_{2} \mathrm{O}_{3}\right)$. Asirvatham et al. [20] conducted a study on the forced convection heat transfer of nanofluid, using a low volume concentration of nanoparticles with water $(\mathrm{CuO} /$ water). The results showed that the convection heat transfer coefficient was improved, even at a low concentration of nanoparticles. They reported that the presence of suspended nanoparticles contributed to an improvement of the thermal conductivity of the nanofluid. Nassan et al. [21] confirmed an improvement of the thermal properties of nanofluids $\left(\mathrm{CuO} /\right.$ water, $\mathrm{Al}_{2} \mathrm{O}_{3} /$ water). It was also reported that the convective heat transfer coefficient of $\mathrm{CuO} /$ water was increased more than that of $\mathrm{Al}_{2} \mathrm{O}_{3}$ /water at the same concentration.

Nanofluids are generally made with metals and metallic oxide nanoparticles, and many studies have been conducted to apply them to various fields (systems for heating and cooling, solar water heating, thermal storage, etc.) by improving the thermal conductivity of conventional heat transfer fluids [22]. Lu et al. [23] studied the thermal performance of an evacuated tubular solar collector with nanofluid ( $\mathrm{CuO} /$ water). By applying the nanofluid, the value of the heat transfer coefficient was improved slightly, with an increase of the heat flux. They reported that the value of the heat transfer coefficient was changed according to the concentration of the nanoparticles, and the mass concentration corresponding to the optimal heat transfer improvement was 1.2\%. Kang et al. [24] conducted an economic analysis of flat-plate and U-tube solar collectors with nanofluid $\left(\mathrm{Al}_{2} \mathrm{O}_{3} /\right.$ water). The flat-plate and U-tube solar collectors using nanofluid with a nanoparticle size of $20 \mathrm{~nm}$ and a concentration of $1.0 \mathrm{vol} \%$ had $14.8 \%$ and $10.7 \%$ higher thermal efficiency values, respectively, compared with utilizing water as the working fluid. Karami and Rahimi [25] performed experiments on the cooling performance of channels using Boehmite $\left(\mathrm{AlOOH} \cdot \mathrm{xH}_{2} \mathrm{O}\right)$ nanofluid for the PV module. The results showed that the nanofluid had better cooling performance than water with the highest electrical efficiency at $0.1 \mathrm{wt} \%$ concentration. Waeil et al. [26] conducted an experimental study on the PVT system using nanofluid ( $\mathrm{SiC} /$ water). As a result, the thermal conductivity of the nanofluid at a concentration of $3 \mathrm{wt} \%$ was improved to $8.2 \%$ in the temperature range of $25^{\circ} \mathrm{C}$ to $60^{\circ} \mathrm{C}$. The overall efficiency of the PVT system 
was about $88.9 \%$, which was high compared to the PV system. Shmani et al. [27] studied a PVT system with various types of nanofluids $\left(\mathrm{SiO}_{2}, \mathrm{TiO}_{2}, \mathrm{SiC}\right)$. Using an $\mathrm{SiC}$ nanofluid, the highest thermal and electrical efficiencies were $81.73 \%$ and $13.52 \%$, respectively. Many studies on the heat transfer characteristics of nanofluids have been carried out, but there is a limit to how accurately one can predict the trend of heat transfer enhancement. There are also many variables in the application of nanofluids, so more theoretical and experimental studies are needed [28].

This study was carried out to improve the efficiency of a PVT system, with a nanofluid as the working fluid, at an optimum flow rate. The role of the working fluid is important in increasing the efficiency of the PVT system. Therefore, the electrical and thermal efficiencies of the PVT system were compared and analyzed with various flow rates of water as the working fluid. In addition, the thermal and electrical efficiencies of the PVT system were investigated using water and nanofluids $(\mathrm{CuO} / \mathrm{water}$, $\mathrm{Al}_{2} \mathrm{O}_{3}$ /water) as working fluids at an optimum flow rate. Nanofluids, for application in the PVT system, are used after surfactant is added for dispersion stability, and the thermal conductivity according to the concentration of surfactant was measured. Additionally, the effects on the performance of the PVT system were investigated using water and nanofluids as working fluids.

\section{Materials and Methods}

\subsection{Experimental Configuration and Methods of the PVT System}

In this study, the flat-plate PVT system consists of the PV module, solar absorbing tube, storage tank, circulating pump, etc. The solar cells in the PV module used in the experiment are monocrystalline silicon, and ten cells were connected in series. A glass cover installed on the front of the PV module was used to reduce the loss of heat energy. The absorbing tube, which is installed under the PV module, was made with copper pipes. A pump and flow meter control the flow rate of the working fluid, assisting the circulation. The storage tank stores the thermal energy of the working fluid circulating inside the absorbing tube of the PVT collector. The specifications of the PVT collector system used in this study are shown in Table 1. The schematic diagram of the PVT system is presented in Figure 1.

Table 1. Specifications of the photovoltaic thermal (PVT) collector.

\begin{tabular}{cc}
\hline Items & Specification \\
\hline Cell type & Mono crystalline \\
No. of cell & 10 \\
Cell dimension $\left(\mathrm{mm}^{2}\right)$ & $156.75 \times 156.75$ \\
Typical module efficiency $(\%)$ & $15-20$ \\
Nominal operation cell temperature $\left({ }^{\circ} \mathrm{C}\right)$ & $45 \pm 2$ \\
The coefficient of $\mathrm{P}_{\max }\left(\% /{ }^{\circ} \mathrm{C}\right)$ & -0.359 \\
The coefficient of $\mathrm{V}_{\mathrm{oc}}\left(\% /{ }^{\circ} \mathrm{C}\right)$ & -0.245 \\
The coefficient of $\mathrm{I}_{\mathrm{sc}}\left(\% /{ }^{\circ} \mathrm{C}\right)$ & 0.024 \\
Absorber type & Tube \\
Collector area $\left(\mathrm{m}^{2}\right)$ & 0.297 \\
Absorbing tube material & Copper \\
\hline
\end{tabular}

The PVT system receives the sun's ray to produce electrical energy from the PV module on the front and absorbs the heat energy through the absorbing tube at the lower part. This is a stationary PVT system that does not track the sun, and it was installed 45 degrees to the full south. In experiments investigating the optimal flow rate, water was used as the working fluid in the PVT system. The working fluid, which is stored in the storage tank, is circulated through the pump to the absorbing tube to obtain the heat energy. Each experiment was conducted for 240 minutes, with the PVT system located at $37^{\circ}$ north latitude and $127^{\circ}$ east longitude. To collect the data for an efficiency analysis, resistance

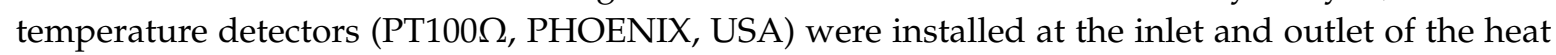
absorbing tube, and thermocouples were installed on the glass surface above the PV module. Measured 
temperatures were collected through a data logger (GL820, GRAP-HTEC, USA). Solar radiation was measured using a pyranometer (EQ-08, Middleton Solar, Victoria, Australia) through the data logger (KL-200, Wellbian system, Seoul, Korea), and the ambient air conditions were measured by a weather station (Wireless Vantage Pro2 Plus, Davis Instruments, Hayward, CA, USA). The values of current, voltage, and power produced by the PV module were collected using a Solar Module Analyzer (PROVA 210, PROVA, Taiwan). The flow rate of the working fluid was controlled through a flow meter (PA-60, KOMETER, Korea), and was set to the flow rate of 1,2,3, and $4 \mathrm{~L} / \mathrm{min}$. Temperature data were obtained in 1 minute increments, and these values were averaged over 10 minutes. The effect of the optimum flow rate of the working fluid on the performance of the PVT system was analyzed and applied to a PVT system with nanofluids.

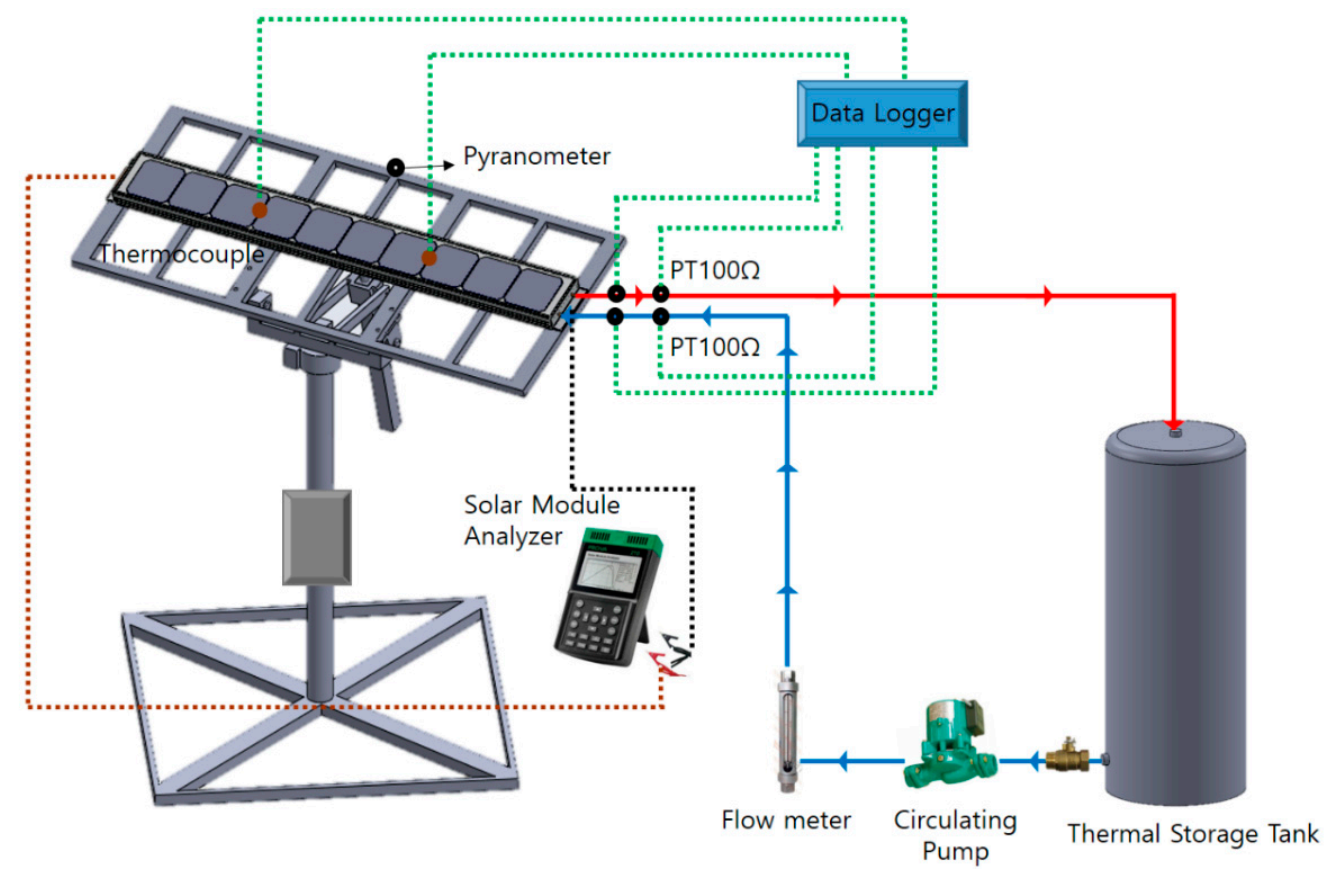

Figure 1. Schematic diagram of a PVT system.

\subsection{Nanofluid Preparation}

Nanofluids were manufactured by dispersing the metallic nanoparticles in distilled water at a concentration of $0.05 \mathrm{wt} . \%$. The nanoparticles used in the study were manufactured and supplied by a company (AVENTION CO., LTD., Incheon, Korea). Figure 2 show the scanning electron microscope images of the nanoparticles. The size of the nanoparticles was $50 \mathrm{~nm}$ to $100 \mathrm{~nm}$ for $\mathrm{CuO}$ and $50 \mathrm{~nm}$ for $\mathrm{Al}_{2} \mathrm{O}_{3}$. Surfactants of CTAB (Cetyltrimethylammonium Bromide) and AG (Arabic Gum) were added for the dispersion stability of the nanoparticles. In this study, the two-step method, which is a way of dispersing nanoparticles in a fluid, was used for the production of the nanofluids. After adding the nanoparticles and surfactant, stirring was conducted with a stirrer (KMC-130SH, VISION SCIENTIFIC, Korea) for $30 \mathrm{~min}$, and dispersing was carried out for $1 \mathrm{~h} 30 \mathrm{~min}$ with an ultrasonicator (KFS-1200N, Korea Process Technology Co., Korea). Li et al. [29] reported that the thermal conductivity of nanofluids decreases after a certain concentration of surfactant. Therefore, the thermal conductivity of nanofluids with various concentrations of the surfactant was investigated in this study. CTAB was added as the surfactant at 1/10, 1, and 10 times CMC (Critical Micelle Concentration), and AG was added at 1/4, 1/2, and 1 times, based on the nanoparticles, because there was no CMC concentration. The stability of the manufactured nanofluids was confirmed visually for several days in a stationary condition. The layer separations of the $\mathrm{Al}_{2} \mathrm{O}_{3}$ /water and $\mathrm{CuO} /$ water nanofluids were started respectively after three and four days of production. However, the long-term stability of nanofluids would be maintained at the state of circulation such as an application as working fluid of the PVT system. The thermal conductivity 
and thermal diffusivity of the nanofluids were measured using a thermal characteristic analyzer (KD2, DECAGON, USA). The measured thermal characteristic values of the nanofluids are shown in Tables 2 and 3 . The results are the average value of 10 total measurements. It was also shown that the thermal characteristics of all nanofluids had statistically significant differences from those of water. Therefore, the $\mathrm{CuO}+\mathrm{AG}\left(1 / 2\right.$ times) and $\mathrm{Al}_{2} \mathrm{O}_{3}+\mathrm{CTAB}(1 / 10$ times) nanofluids, which showed the highest values of thermal conductivity, were selected and used in the experiments for efficiency analysis of the PVT system. The values of thermal conductivity were $0.901 \mathrm{~W} / \mathrm{m} \cdot{ }^{\circ} \mathrm{C}$ and $0.829 \mathrm{~W} / \mathrm{m} \cdot{ }^{\circ} \mathrm{C}$ for $\mathrm{CuO}+\mathrm{AG}$ (1/2 times) and $\mathrm{Al}_{2} \mathrm{O}_{3}+\mathrm{CTAB}(1 / 10$ times), respectively.

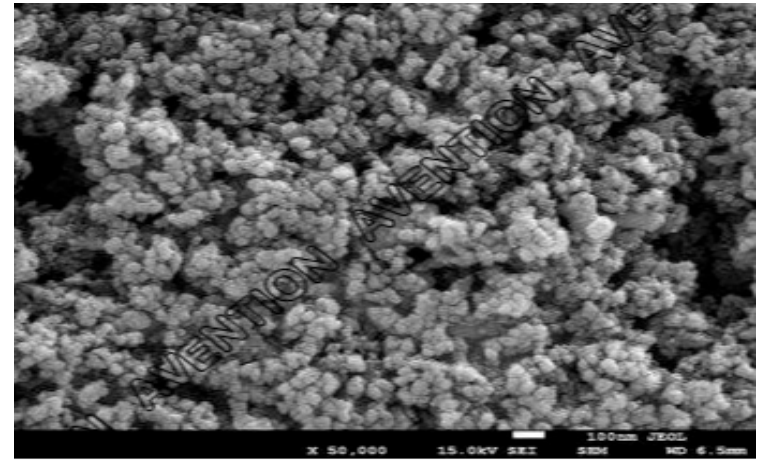

(a)

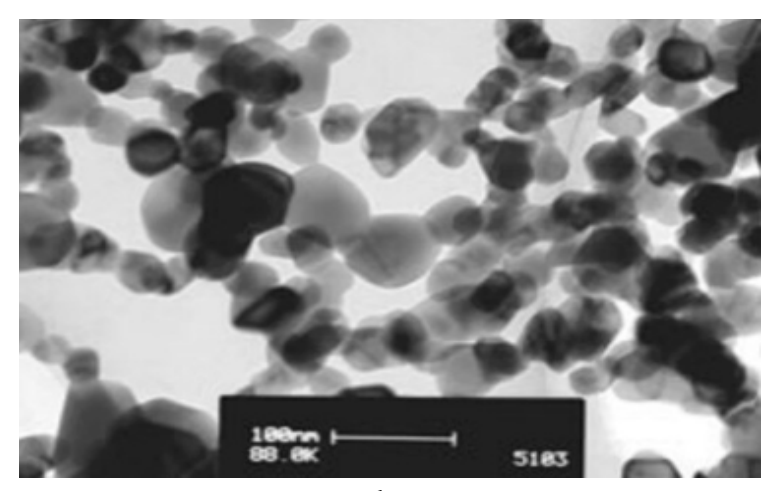

(b)

Figure 2. Scanning electron microscope (SEM) images of the nanoparticles: (a) $\mathrm{Al}_{2} \mathrm{O}_{3}$ nanoparticles; (b) $\mathrm{CuO}$ nanoparticles [30].

Table 2. Thermal characteristic values of $\mathrm{CuO} /$ water nanofluids. AG, Arabic gum; CTAB, Cetyltrimethylammonium Bromide.

\begin{tabular}{ccc}
\hline Surfactant (Concentration) & Thermal Conductivity $\left(\mathbf{W} / \mathbf{m}^{\circ}{ }^{\circ} \mathbf{C}\right)$ & Thermal Diffusivity $\left(\mathbf{m m}^{\mathbf{2}} / \mathbf{s}\right)$ \\
\hline AG $(1 / 4)$ & 0.851 & 0.262 \\
AG $(1 / 2)$ & 0.901 & 0.314 \\
AG $(1)$ & 0.781 & 0.21 \\
CTAB $(1 / 10)$ & 0.783 & 0.214 \\
CTAB (1) & 0.774 & 0.207 \\
CTAB $(10)$ & 0.765 & 0.204 \\
\hline
\end{tabular}

Table 3. Thermal characteristic values of $\mathrm{Al}_{2} \mathrm{O}_{3} /$ water nanofluids.

\begin{tabular}{ccc}
\hline Surfactant (Concentration) & Thermal Conductivity $\left(\mathbf{W} / \mathbf{m}^{\circ}{ }^{\circ} \mathbf{C}\right)$ & Thermal Diffusivity $\left(\mathbf{m m}^{\mathbf{2}} / \mathbf{s}\right)$ \\
\hline AG $(1 / 4)$ & 0.795 & 0.216 \\
AG $(1 / 2)$ & 0.811 & 0.241 \\
AG $(1)$ & 0.815 & 0.257 \\
CTAB (1/10) & 0.829 & 0.214 \\
CTAB (1) & 0.788 & 0.214 \\
CTAB (10) & 0.778 & 0.208 \\
\hline
\end{tabular}

\subsection{Efficiency Calculation}

\subsubsection{Thermal Efficiency}

To obtain the thermal efficiency of the PVT system, the collected heat $\left(Q_{t}\right)$ was calculated by Equation (1):

$$
Q_{t}=\dot{m} C_{p}\left(T_{o}-T_{i}\right)
$$

where $\dot{m}$ is the mass flow rate, $C_{p}$ is the specific heat, and $T_{o}$ and $T_{i}$ are the temperatures of the working fluid located at the outlet and inlet of the heat absorbing tube. The thermal efficiency of the PVT system 
is defined by Equation (2) and Equation (3). The key parameters, which are used to define the thermal efficiency $\left(\eta_{t h}\right)$, include the collected heat $\left(Q_{t}\right)$, collector area $(\mathrm{A})$, and solar radiation $\left(I_{a}\right)$ :

$$
\begin{gathered}
\eta_{t h}=\frac{Q_{t}}{A I_{a}} \\
\eta_{t h}=\eta_{0}-\alpha\left(\frac{T_{i}-T_{a}}{I_{a}}\right)
\end{gathered}
$$

where $\eta_{0}$ is the thermal efficiency when the difference between the inlet temperature $\left(T_{i}\right)$ and the ambient air temperature $\left(T_{a}\right)$ is zero, and $\alpha$ is the heat loss coefficient.

\subsubsection{Electrical Efficiency}

The electrical efficiency $\left(\eta_{e}\right)$ is defined as Equations (4) and (5):

$$
\begin{gathered}
P_{\max }=V_{o c} I_{s c} F F=V_{\max } I_{\max } \\
\eta_{e}=\frac{P_{\max }}{A I_{a}}
\end{gathered}
$$

where $P_{\max }$ is the maximum electrical power, $V_{o c}$ is the open-circuit voltage, $I_{s c}$ is the short-circuit current, and FF is the fill factor. A solar module analyzer was used as the measuring equipment for the electrical efficiency, providing the maximum voltage $\left(V_{\max }\right)$, maximum current $\left(I_{\max }\right)$, and maximum electrical power $\left(P_{\max }\right)$ values.

\subsubsection{Overall Efficiency}

Several researchers have shown overall efficiency through Equation (6) when evaluating the PVT system [31]. The overall efficiency $\left(\eta_{0}\right)$ is simply expressed as the sum of the thermal and electrical efficiencies:

$$
\eta_{o}=\eta_{t h}+\eta_{e}
$$

Electrical power and thermal energy have different forms. Electrical energy is considered a high-grade form, because it is converted from thermal energy. Therefore, for an accurate overall evaluation of the PVT system, Huang [32] defined the energy saving efficiency $\left(\eta_{f}\right)$ as Equation (7):

$$
\eta_{f}=\eta_{t h}+\frac{\eta_{e}}{\eta_{\text {power }}}
$$

where $\eta_{\text {power }}$ is the electric-power generation efficiency of the conventional electric power plant, and this value is taken as 0.38 .

\section{Results and Discussion}

\subsection{The PVT System with its Flow Rate}

The experiments for investigating the optimal flow rate were conducted in June 2018, and water was used as the working fluid. The outdoor environmental conditions for the experiments are shown in Table 4.

Table 4. The experimental environmental conditions and flow rates.

\begin{tabular}{lcccc}
\hline Flow Rate & Solar Radiation $\left(\mathbf{W} / \mathbf{m}^{2}\right)$ & Wind Speed $(\mathbf{m} / \mathbf{s})$ & $\begin{array}{c}\text { Ambient } \\
\text { Temperature }\left({ }^{\circ} \mathbf{C}\right)\end{array}$ & Inlet Temperature $\left({ }^{\circ} \mathbf{C}\right)$ \\
\hline 1 L/min & $732.7-893$ & $0.4-1.8$ & $29.1-34$ & $29.3-38.86$ \\
$4 \mathrm{~L} / \mathrm{min}$ & & & & $29.5-38.16$ \\
2 L/min & $713.67-931.67$ & $0-1.8$ & $25.7-30.1$ & $26.94-37.97$ \\
$3 \mathrm{~L} / \mathrm{min}$ & & & $26.05-35.85$ \\
\hline
\end{tabular}




\subsubsection{Thermal Efficiency Analysis}

Figure 3 shows the change of the thermal efficiency for each flow rate of the PVT system over time. The experimental results showed that the optimum flow rate was $3 \mathrm{~L} / \mathrm{min}$. The average thermal efficiency at a flow rate of $3 \mathrm{~L} / \mathrm{min}$ was $23.59 \%$, with a maximum and minimum of $30.17 \%$ and $17.67 \%$, respectively. As the flow rate was increased from $1 \mathrm{~L} / \mathrm{min}$ to $3 \mathrm{~L} / \mathrm{min}$, the thermal efficiency tended to increase, although it decreased at $4 \mathrm{~L} / \mathrm{min}$. It is suggested that a flow rate above $3 \mathrm{~L} /$ min shortened the residence time of the working fluid in the absorbing tube, so it could not obtain enough solar energy. Figure 4 shows the thermal efficiency according to $\left(T_{i}-T_{a}\right) / I$, which is an indicator for evaluating the performance of a solar collector in terms of convection heat loss. As $\left(T_{i}-T_{a}\right) / I$ was increased, the flow rates of $1,2,3$, and $4 \mathrm{~L} / \mathrm{min}$ showed a reduction in thermal efficiency due to an increase of convection heat loss. The average thermal efficiency at a flow rate of $3 \mathrm{~L} / \mathrm{min}$ was the highest, with a maximum of $29.46 \%$ when the difference between the inlet temperature and ambient temperature was zero. However, if the temperature of the working fluid increased after receiving solar radiation for a long period of time, the heat loss to the ambient air was also greatly increased compared to other flow rates, decreasing the thermal efficiency.

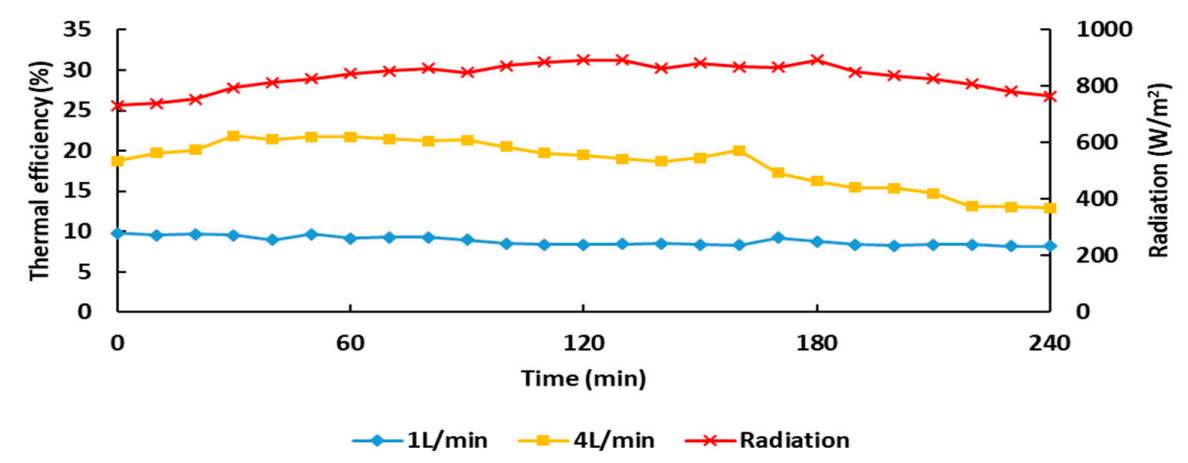

(a)

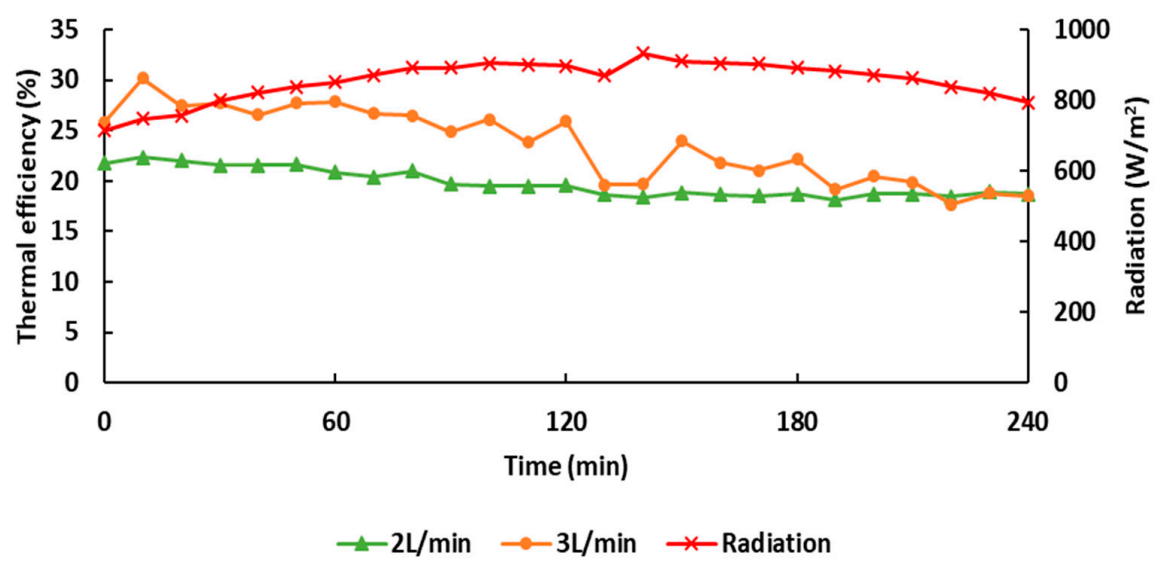

(b)

Figure 3. The thermal efficiency and solar radiation for each flow rate of the PVT system over time: (a) flow rates of $1 \mathrm{~L} / \mathrm{min}$ and $4 \mathrm{~L} / \mathrm{min}$; (b) flow rates of $2 \mathrm{~L} / \mathrm{min}$ and $4 \mathrm{~L} / \mathrm{min}$.

\subsubsection{Electrical Efficiency Analysis}

Figure 5 shows the change in the electrical efficiency for each flow rate of the PVT system over time. The average electrical efficiency was the highest at a flow rate of $3 \mathrm{~L} / \mathrm{min}$, at $12.08 \%$ but was around $12 \%$ for the other flow rates. Figure 6 shows the electrical efficiency according to the surface temperature of a solar cell. The electrical efficiency of a typical solar cell is affected by several conditions, such as the surface temperature or amount of solar energy. In particular, electricity is produced through solar energy, but as solar radiation is concentrated, the surface temperature of the solar cell increases and 
the electrical efficiency tends to decrease. The results also show that the electrical efficiency decreases as the surface temperature increases. In this study, the average surface temperature of the solar cell was $43.96{ }^{\circ} \mathrm{C}$ at $1 \mathrm{~L} / \mathrm{min}, 42.64{ }^{\circ} \mathrm{C}$ at $2 \mathrm{~L} / \mathrm{min}, 41.67{ }^{\circ} \mathrm{C}$ at $3 \mathrm{~L} / \mathrm{min}$, and $42.08^{\circ} \mathrm{C}$ at $4 \mathrm{~L} / \mathrm{min}$. The surface temperature of the solar cell was the lowest at $3 \mathrm{~L} / \mathrm{min}$, which has the highest thermal efficiency because it most effectively absorbs the heat energy generated from the PVT system through the working fluid. However, it is suggested that the difference in the efficiency of each flow rate is not as large as expected because the reduction rate of the $P_{\max }$ per the temperature rise of $1{ }^{\circ} \mathrm{C}$ is very small at $0.359 \%$.

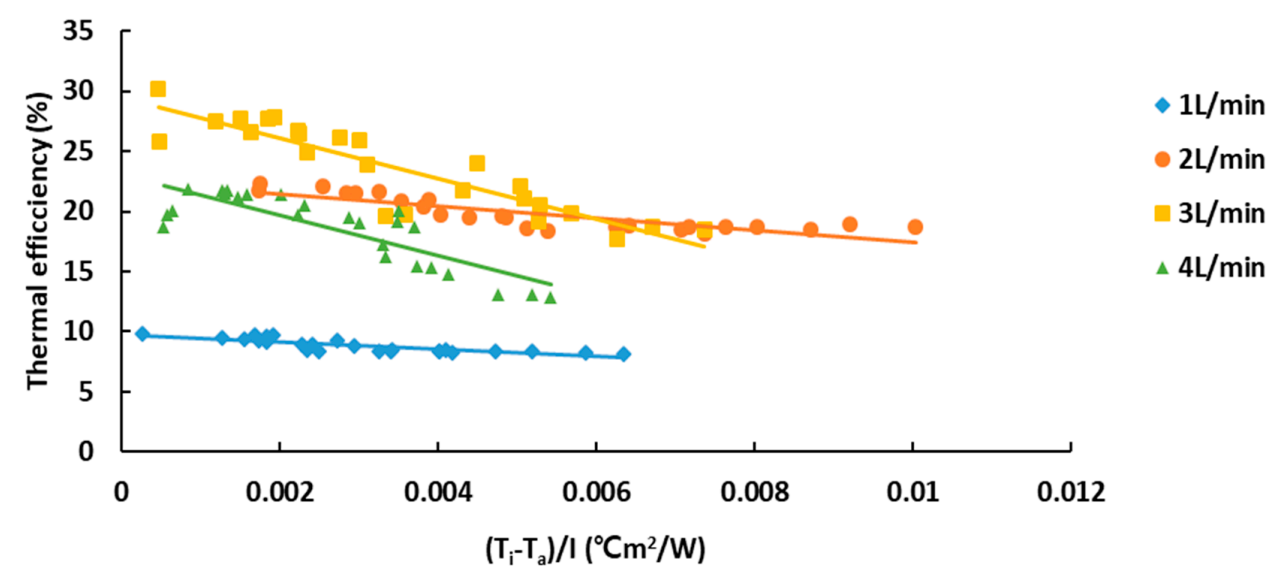

Figure 4. The thermal efficiency for each flow rate of the PVT system according to $\left(T_{i}-T_{a}\right) / I$.

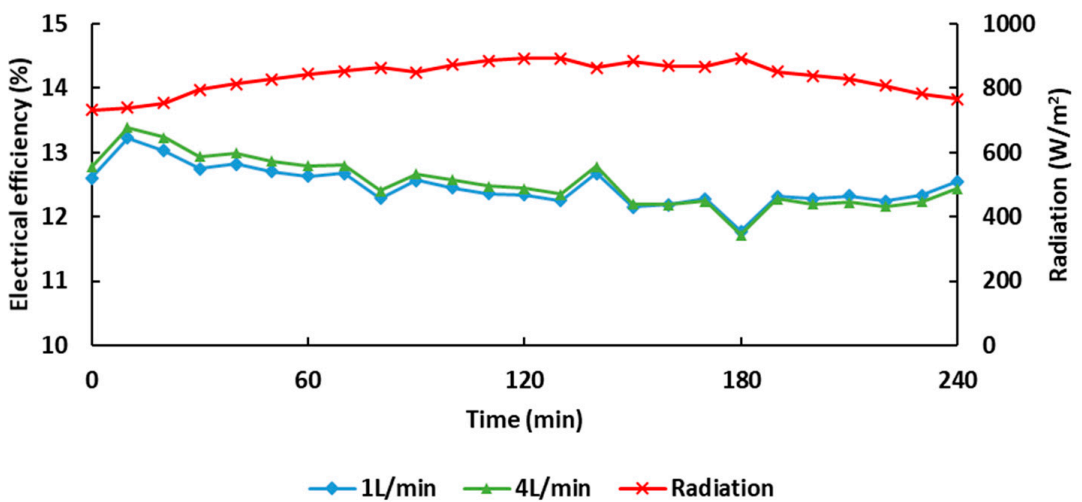

(a)

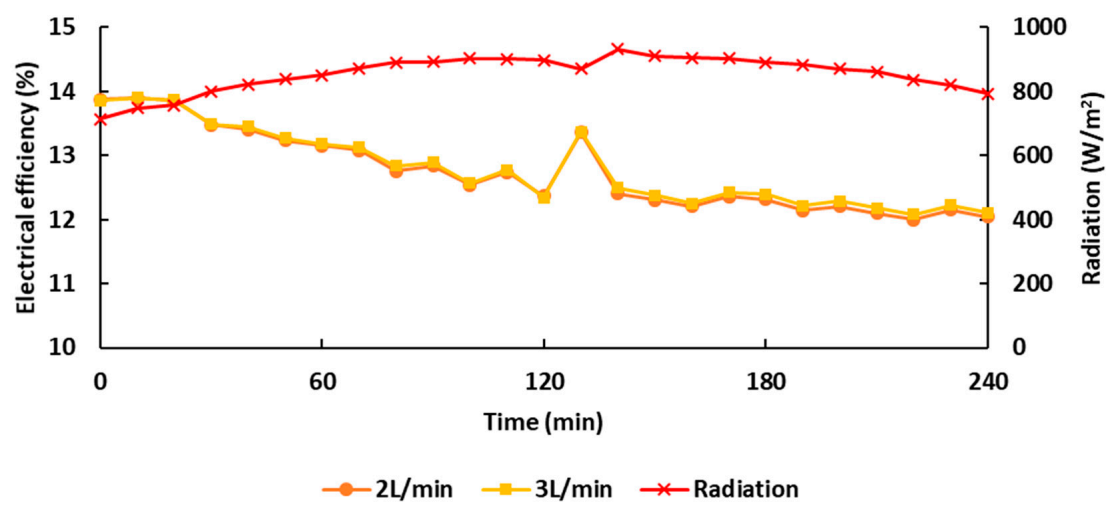

(b)

Figure 5. The electrical efficiency and solar radiation for each flow rate of the PVT system over time: (a) the flow rates of $1 \mathrm{~L} / \mathrm{min}$ and $4 \mathrm{~L} / \mathrm{min}$; (b) the flow rates of $2 \mathrm{~L} / \mathrm{min}$ and $3 \mathrm{~L} / \mathrm{min}$. 


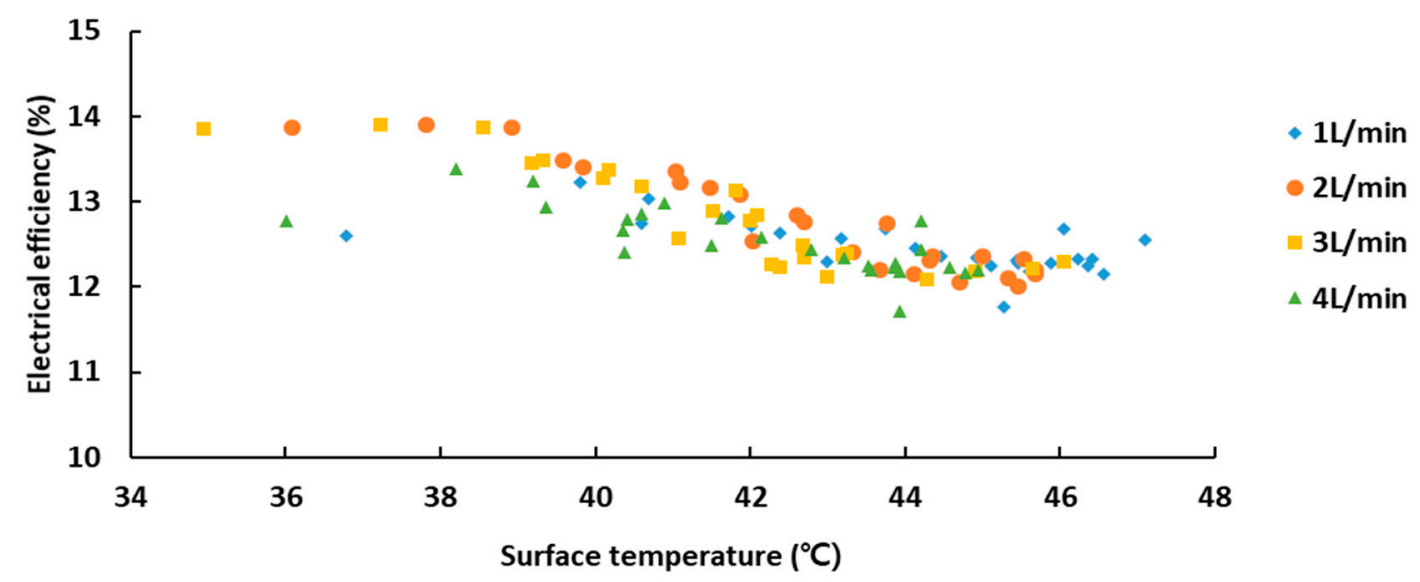

Figure 6. The electrical efficiency for each flow rate of the PVT system according to the surface temperature of the solar cell.

\subsubsection{Overall Efficiency Analysis}

With a flow rate of $3 \mathrm{~L} / \mathrm{min}$, the overall energy saving efficiencies were $36.39 \%$ and $57.28 \%$, respectively, which were higher than those of the other flow rates. Therefore, according to the efficiency analysis, the optimal flow rate was found to be $3 \mathrm{~L} / \mathrm{min}$ for the PVT system with water as the working fluid. The results of the efficiency analysis of the PVT system with each flow rate are shown in Table 5.

Table 5. The average efficiency of the PVT system for each flow rate.

\begin{tabular}{ccccc}
\hline Flow Rate & $\eta_{\boldsymbol{t h}} \mathbf{( \% )}$ & $\eta_{\boldsymbol{e}} \mathbf{( \% )}$ & $\eta_{\boldsymbol{o}} \mathbf{( \% )}$ & $\eta_{\boldsymbol{f}} \mathbf{( \% )}$ \\
\hline 1 L/min & 8.82 & 12.47 & 21.29 & 41.64 \\
2 L/min & 19.79 & 12.75 & 32.54 & 53.35 \\
3 L/min & 23.59 & 12.80 & 36.39 & 57.28 \\
$4 \mathrm{~L} / \mathrm{min}$ & 18.56 & 12.54 & 31.09 & 51.55 \\
\hline
\end{tabular}

\subsection{The PVT System Using Nanofluids}

To improve the performance of the PVT system, an efficiency analysis with a nanofluid as the working fluid was conducted. The water-based PVT system was set as the control to confirm the efficiency improvement of the PVT system using a nanofluid as the working fluid. Two experiments on the PVT system with nanofluids were carried out on different days in May 2019. The weather data for each day of the experiments are shown in Table 6.

Table 6. The experimental environmental conditions and nanofluids.

\begin{tabular}{ccccc}
\hline Nanofluids & $\begin{array}{c}\text { Solar Radiation } \\
\left(\mathbf{W} / \mathbf{m}^{\mathbf{2}}\right)\end{array}$ & Wind Speed $(\mathbf{m} / \mathbf{s})$ & $\begin{array}{c}\text { Ambient } \\
\text { Temperature }\left({ }^{\circ} \mathbf{C}\right)\end{array}$ & Inlet Temperature $\left({ }^{\circ} \mathbf{C}\right)$ \\
\hline $\mathrm{CuO} /$ water & $733.89-958.22$ & $0.9-4$ & $18.58-25.52$ & $23.4-39.16$ \\
$\mathrm{Al}_{2} \mathrm{O}_{3} /$ water & $797-977$ & $0-1.3$ & $22-30.52$ & $23.3-45.48$ \\
\hline
\end{tabular}

\subsubsection{Efficiency Analysis of the PVT System Using CuO/Water as the Nanofluid}

The changes in the thermal efficiency of the water and $\mathrm{CuO} /$ water-based PVT systems over time are shown in Figure 7. The thermal efficiencies of the PVT system with $\mathrm{CuO} /$ water as the nanofluid and the water-based system were $48.88 \%$ and $27.58 \%$, respectively. The electrical efficiency of the water and $\mathrm{CuO} /$ water-based PVT systems over time is presented in Figure 8. The electrical efficiency of the PVT system using $\mathrm{CuO} /$ water as the nanofluid was $13.20 \%$, compared to $13.13 \%$ for the water-based system. 

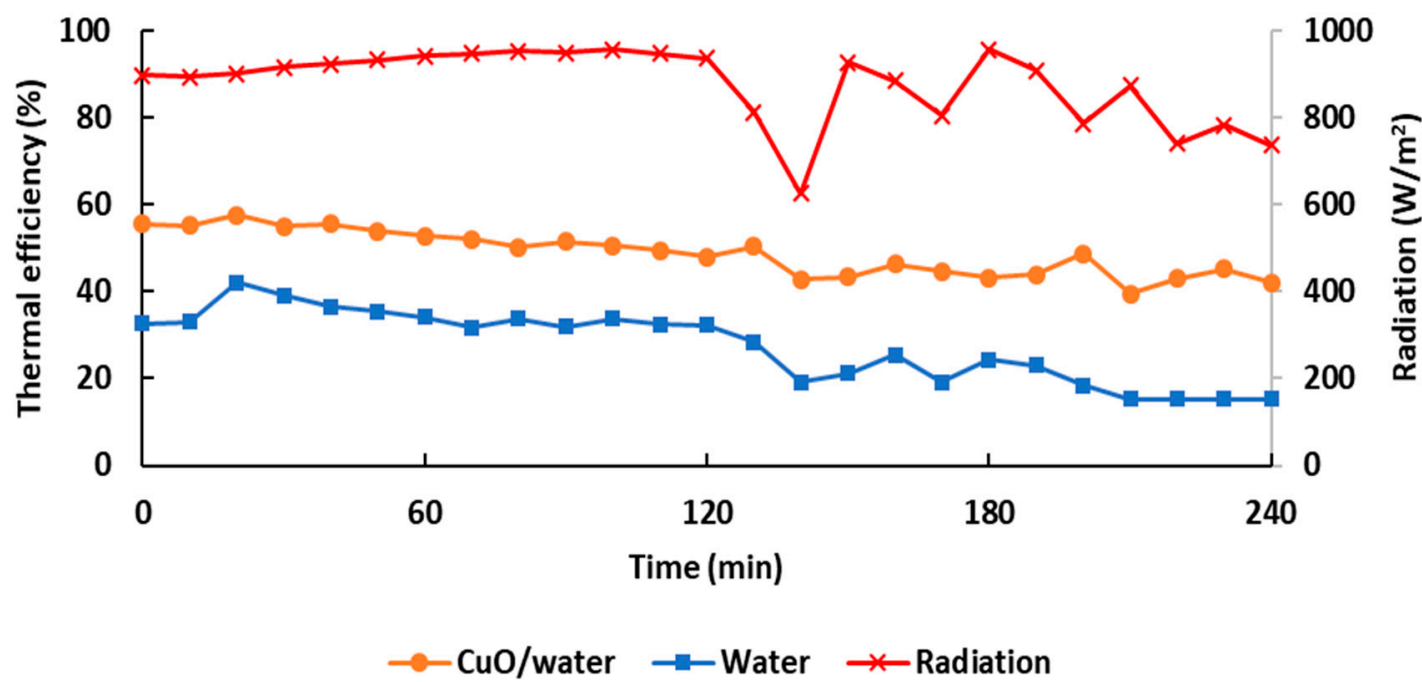

Figure 7. The thermal efficiency and solar radiation of the water and $\mathrm{CuO} /$ water nanofluid-based PVT systems over time.

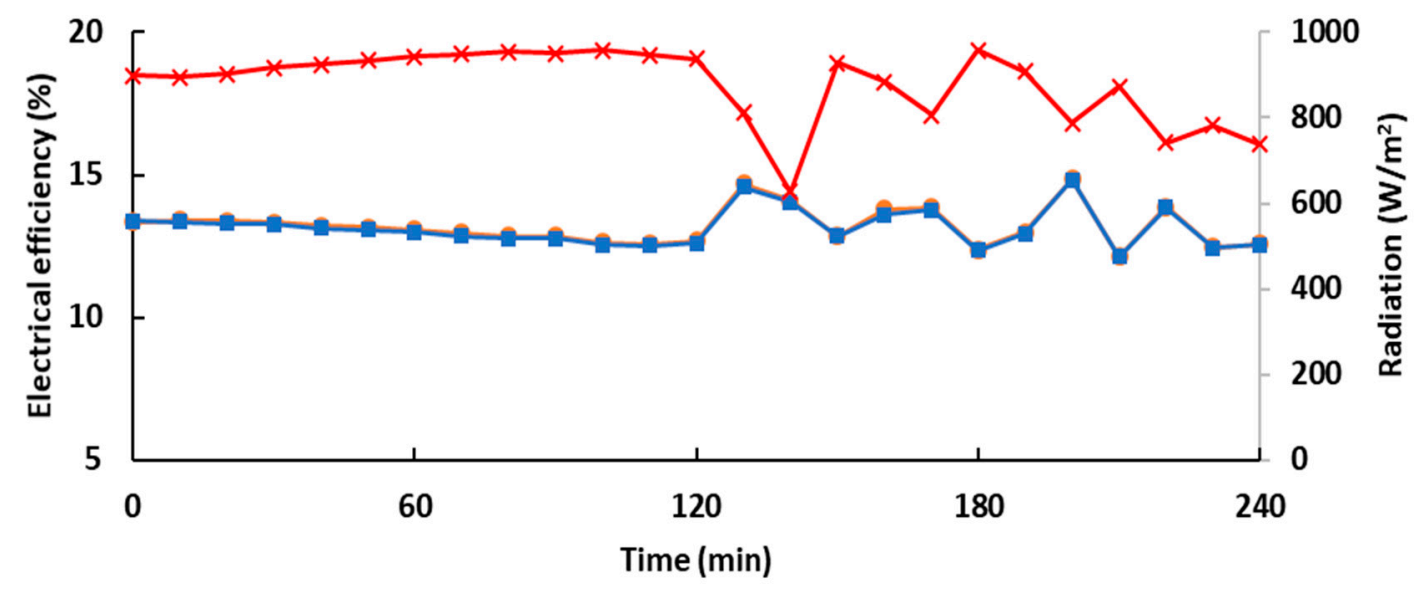

$\rightarrow-\mathrm{CuO} /$ water $\rightarrow-$ Water $\rightarrow$ Radiation

Figure 8. The electrical efficiency solar radiation of the water and $\mathrm{CuO} /$ water nanofluid-based PVT systems over time.

In this study, the thermal efficiency of the PVT system with $\mathrm{CuO} /$ water as the nanofluid was increased by $21.30 \%$. The increase in electrical efficiency was $0.07 \%$, with no significance due to the accuracy of measurement. The thermal efficiency of the $\mathrm{CuO} /$ water-based PVT system was improved because more thermal energy was absorbed due to the increased thermal conductivity of the nanofluid. The thermal efficiencies of water and $\mathrm{CuO} /$ water-based PVT systems according to $\left(T_{i}-T_{a}\right) / I$ are shown in Figure 9. When the difference between the inlet and ambient air temperature was zero, the maximum efficiency of the $\mathrm{CuO} /$ water-based PVT system was $61.16 \%$, compared with $49.65 \%$ for the water-based system. As the value of $\left(T_{i}-T_{a}\right) / I$ increased, the thermal efficiency tended to decrease. It is expected that the heat loss was caused by the temperature difference between the working fluid and the ambient air. Figure 10 presents the electrical efficiency according to the surface temperature of water and $\mathrm{CuO} /$ water-based PVT systems. As the results show, the increase in the surface temperature of the $\mathrm{CuO} /$ water-based system was $1.41^{\circ} \mathrm{C}$, which was lower than that of the water-based system. Therefore, it was difficult to find a difference in the electrical efficiency between the water and $\mathrm{CuO} /$ water-based systems, because the surface temperature difference between the two systems was low, similar to the experimental results of the PVT system with water at various flow rates. The overall and energy saving efficiencies of the $\mathrm{CuO} /$ water-based PVT system were $62.08 \%$ and 
$83.62 \%$, respectively, and they were $21.37 \%$ and $21.49 \%$ higher than those of the water-based-system. The values of the average and overall efficiencies are presented in Table 7.

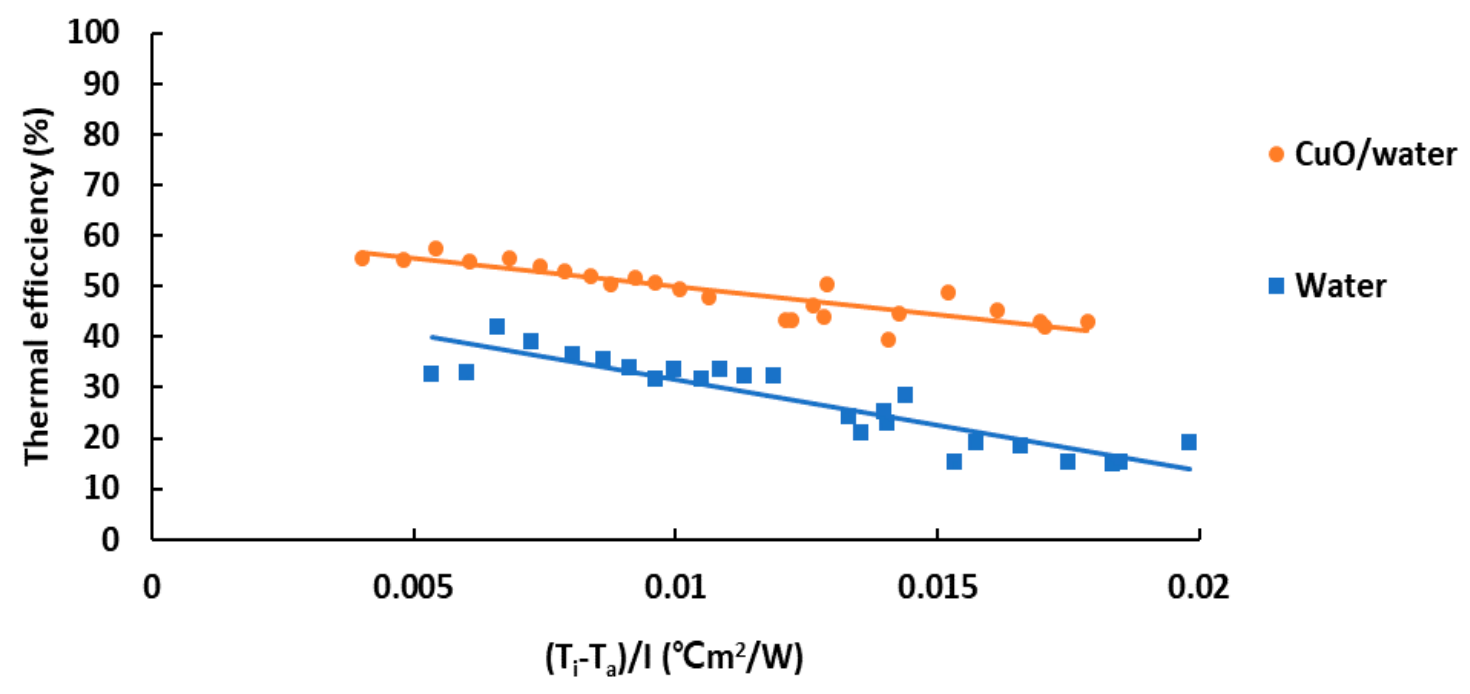

Figure 9. The thermal efficiency of water and $\mathrm{CuO} /$ water nanofluid-based PVT systems according to $\left(T_{i}-T_{a}\right) / I$.

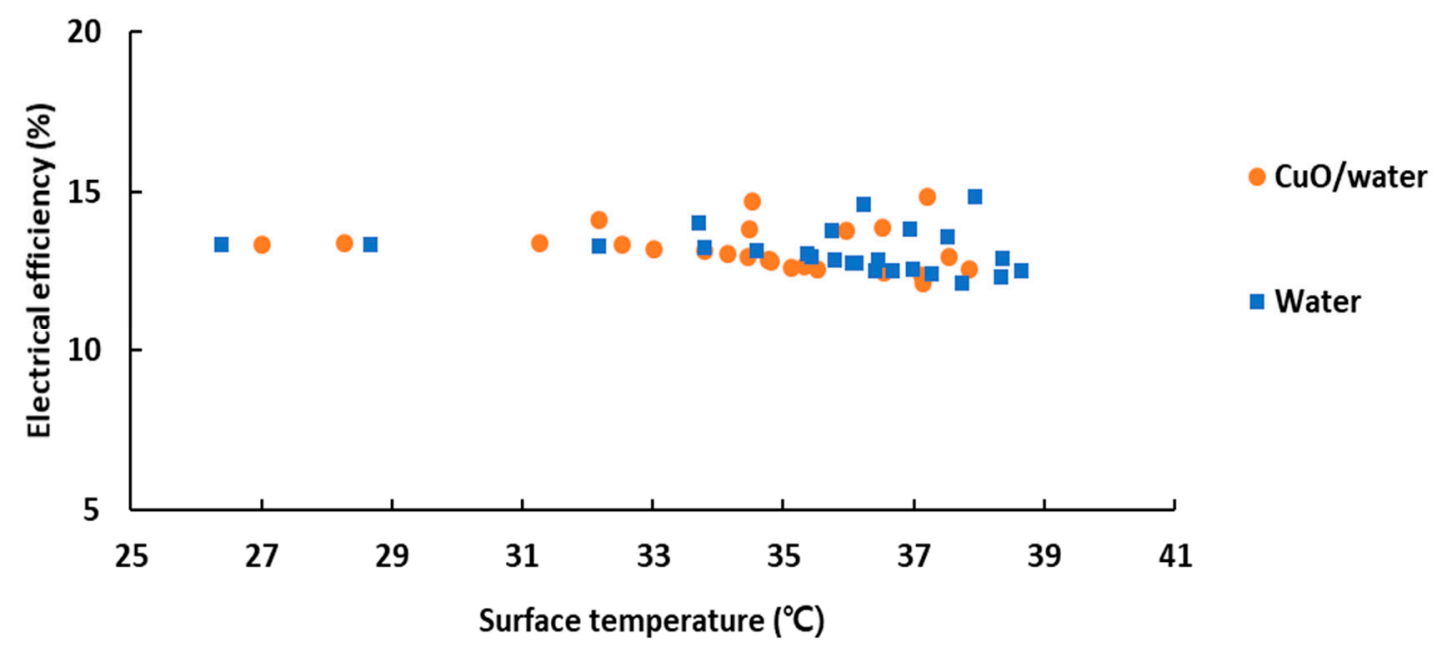

Figure 10. The electrical efficiency of water and $\mathrm{CuO} /$ water nanofluid-based PVT systems according to the surface temperature of the solar cell.

Table 7. The average efficiency of the PVT system using the $\mathrm{CuO} /$ water nanofluid.

\begin{tabular}{ccccc}
\hline Working Fluid & $\eta_{t h} \mathbf{( \% )}$ & $\eta_{\boldsymbol{e}} \mathbf{( \% )}$ & $\eta_{\boldsymbol{o}}(\mathbf{\%})$ & $\eta_{f}(\mathbf{\%})$ \\
\hline CuO/water & 48.88 & 13.20 & 62.08 & 83.62 \\
Nanofluid & 27.58 & 13.13 & 40.71 & 62.13 \\
Water &
\end{tabular}

Michael and Iniyan [33] compared the thermal and electrical performances of the PVT systems using $\mathrm{CuO} /$ water as the nanofluid and water. As the results show, the maximum thermal efficiency of the nanofluid system was improved by $9.43 \%$ compared to the water, showing the same trend as our results, but the electrical efficiency decreased slightly by $0.22 \%$. Al-Waeli et al. [34] investigated the impact of nanofluids $\left(\mathrm{Al}_{2} \mathrm{O}_{3}, \mathrm{CuO}, \mathrm{SiC}\right)$ on the PVT system. They found that the efficiency of the PVT systems using nanofluid was higher than that of water, as was suggested in our study. Even though the electrical efficiency decreased as the luminous intensity increased due to the rising solar cell 
temperature, the use of nanofluids is considered to improve the cooling of the solar cell, thereby increasing electrical performance.

\subsubsection{Efficiency Analysis of the PVT System Using $\mathrm{Al}_{2} \mathrm{O}_{3} /$ water as the Nanofluid}

The thermal and electrical efficiencies of the water and $\mathrm{Al}_{2} \mathrm{O}_{3} /$ water-based PVT systems over time are shown in Figures 11 and 12, respectively. The thermal efficiencies of the water and $\mathrm{Al}_{2} \mathrm{O}_{3} /$ water-based PVT systems were $31.81 \%$ and $46.95 \%$, respectively. The electrical efficiencies were $12.21 \%$ and $12.22 \%$ for the water and $\mathrm{Al}_{2} \mathrm{O}_{3} /$ water-based systems, respectively.

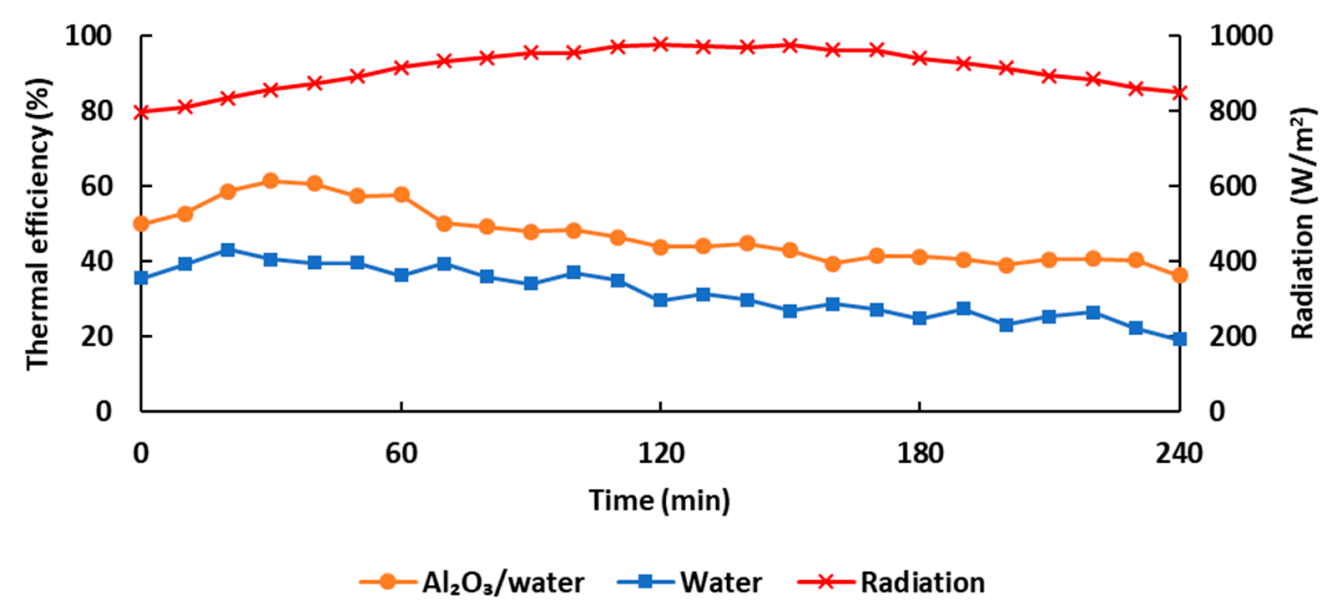

Figure 11. The thermal efficiency and solar radiation of water and $\mathrm{Al}_{2} \mathrm{O}_{3} /$ water nanofluid-based PVT systems over time.

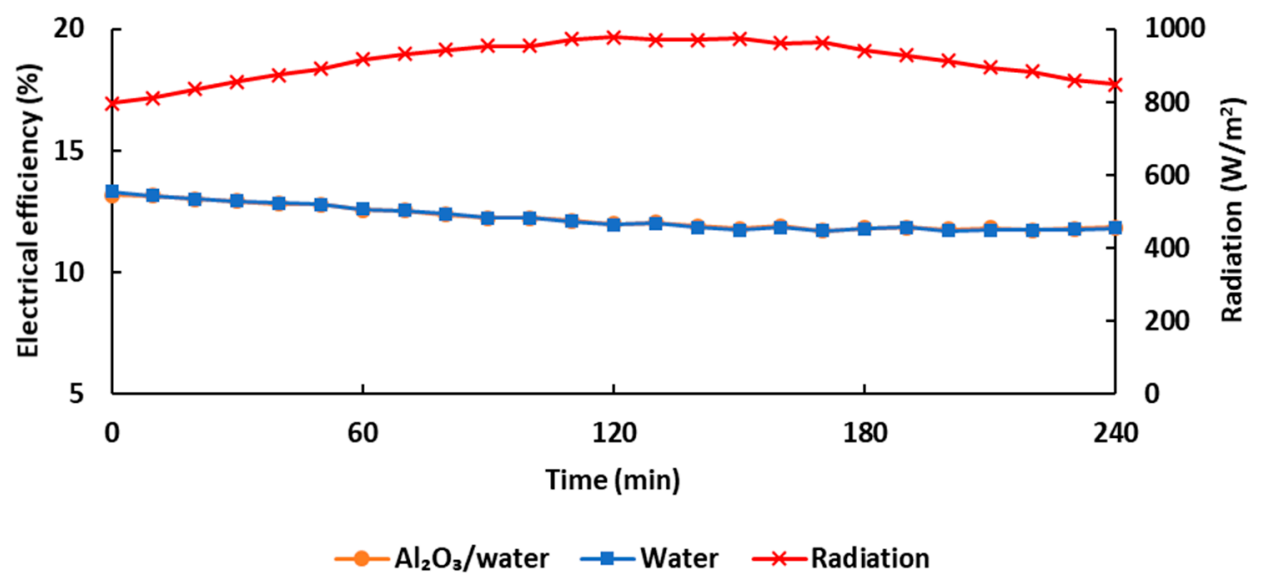

Figure 12. The electrical efficiency of water and $\mathrm{Al}_{2} \mathrm{O}_{3}$ /water nanofluid-based PVT systems over time.

In this study, the PVT system using $\mathrm{Al}_{2} \mathrm{O}_{3} /$ water as the nanofluid achieved an improvement of $15.14 \%$ in thermal efficiency. There was no difference in the electrical efficiency between water and $\mathrm{Al}_{2} \mathrm{O}_{3} /$ water-based systems. The results of the efficiency analysis for PVT systems using $\mathrm{Al}_{2} \mathrm{O}_{3} /$ water and water, according to $\left(T_{i}-T_{a}\right) / I$, are shown in Figure 13. When the difference between the inlet and ambient air temperature was zero, the maximum efficiency of the $\mathrm{Al}_{2} \mathrm{O}_{3}$ /water-based PVT system was $60.98 \%$, compared with $43.06 \%$ for the water system. Figure 14 presents the electrical efficiency according to the surface temperature of the water and $\mathrm{Al}_{2} \mathrm{O}_{3}$ /water-based PVT systems. The surface temperature increase of $\mathrm{Al}_{2} \mathrm{O}_{3}$ /water was $1.12{ }^{\circ} \mathrm{C}$, which was lower than that of water. Overall efficiencies and energy saving efficiencies of the $\mathrm{Al}_{2} \mathrm{O}_{3}$ /water-based PVT system were $15.15 \%$ and $15.17 \%$, respectively, which were higher than those of the water-based system. The efficiency values are shown in Table 8. 


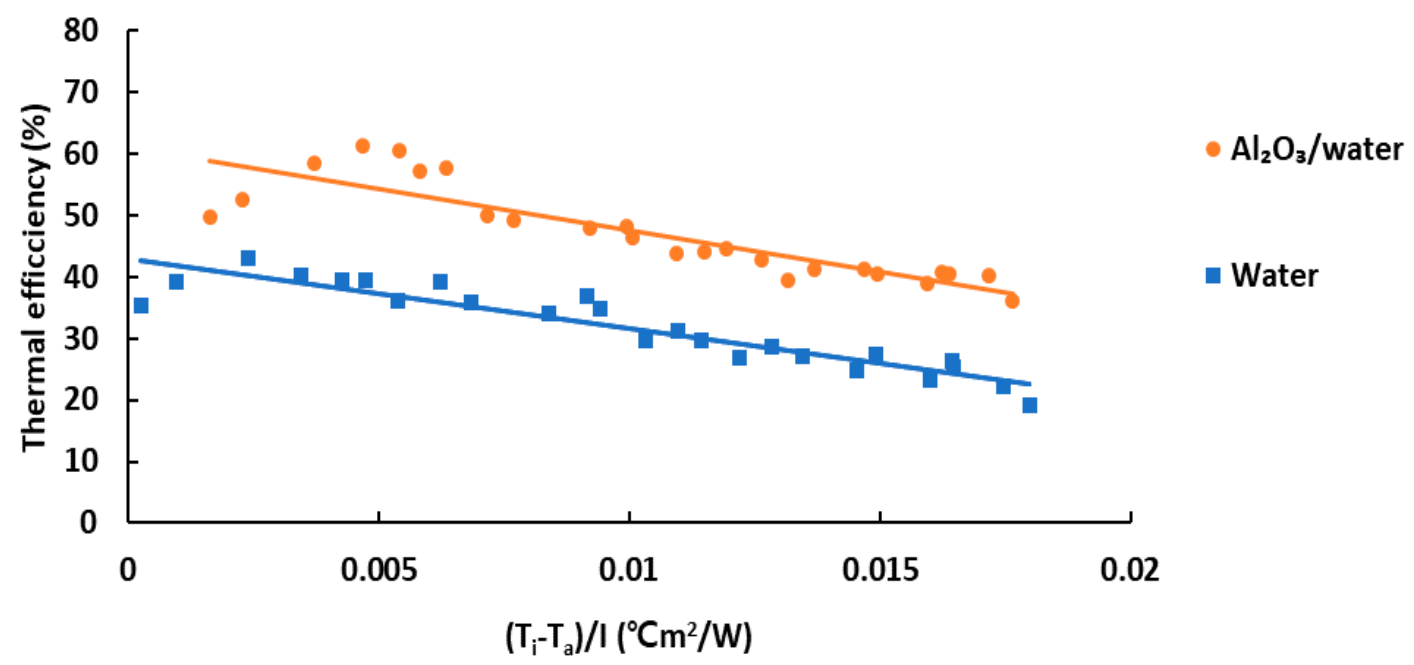

Figure 13. The thermal efficiency of water and $\mathrm{Al}_{2} \mathrm{O}_{3} /$ water nanofluid-based PVT systems according to $\left(T_{i}-T_{a}\right) / I$.

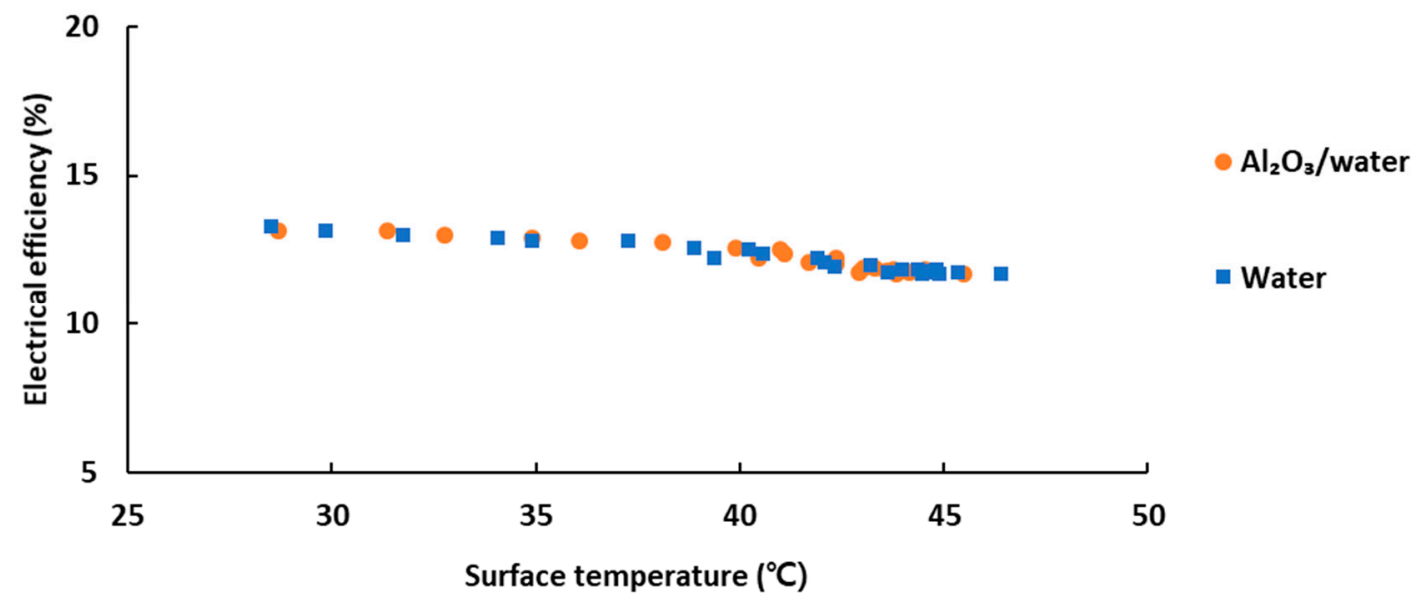

Figure 14. The electrical efficiency of water and $\mathrm{Al}_{2} \mathrm{O}_{3} /$ water nanofluid-based PVT systems according to the surface temperature of the solar cell.

Table 8. The average efficiency of the PVT system using an $\mathrm{Al}_{2} \mathrm{O}_{3} /$ water nanofluid.

\begin{tabular}{ccccc}
\hline Working Fluid & $\eta_{\boldsymbol{t h}} \mathbf{( \% )}$ & $\eta_{\boldsymbol{e}} \mathbf{( \% )}$ & $\eta_{\boldsymbol{o}} \mathbf{( \% )}$ & $\eta_{f}(\mathbf{\%})$ \\
\hline $\mathrm{Al}_{2} \mathrm{O}_{3} /$ water & 46.95 & 12.22 & 59.17 & 79.11 \\
Nanofluid & 31.81 & 12.21 & 44.02 & 63.94 \\
Water &
\end{tabular}

Sardarabadi and Passandideh-Fard [35] experimentally and numerically investigated the use of metal-oxides $\left(\mathrm{Al}_{2} \mathrm{O}_{3}, \mathrm{TiO}_{2}, \mathrm{ZnO}\right) /$ water as the working fluids in PVT systems. As the results show, the increase of the average electrical efficiency of the PVT system compared with the PV were $5.48 \%$ and $6.36 \%$ using water and $\mathrm{Al}_{2} \mathrm{O}_{3} /$ water as the working fluids, respectively. This suggests that nanofluid increased the efficiency of the PVT system more than water, as the results of our study found. Additionally, the reduction of the surface temperature of the PVT system compared to the PV system was $11.0^{\circ} \mathrm{C}$ and $11.03^{\circ} \mathrm{C}$ for water and $\mathrm{Al}_{2} \mathrm{O}_{3}$ /water, respectively. Thus, nanofluid had a significant impact by increasing the thermal efficiency of the PVT system, as was presented in our study. Tang and Zhu [36] compared the efficiency of PVT systems using $\mathrm{Al}_{2} \mathrm{O}_{3}$ /water and water as the working fluids. The $\mathrm{Al}_{2} \mathrm{O}_{3} /$ water-based system had $0.56 \%$ lower electrical efficiency than the water-based system, with a higher thermal efficiency of $26.87 \%$. They concluded that the reason for the lower electrical efficiency was the inlet temperature of the nanofluid being higher than that of water, 
decreasing the conversion efficiency of the solar cell. However, in our study, the surface temperature differences of the PVT systems using water and nanofluids were not significant in terms of affecting the electrical efficiency.

\section{Conclusions}

This study compared thermal efficiency based on the flow rate of a PVT system using water as the working fluid. Based on the results of the thermal efficiency analysis, an optimum flow rate of $3 \mathrm{~L} / \mathrm{min}$ was deduced. At a $3 \mathrm{~L} / \mathrm{min}$ rate, the thermal, electrical, overall, and energy saving efficiencies were $23.59 \%, 12.80 \%, 36.39 \%$, and $57.28 \%$, respectively, which were the highest among the other flow rates. The efficiency of a nanofluid-based PVT system was also analyzed, with an optimal flow rate of $3 \mathrm{~L} / \mathrm{min}$.

The nanofluids used in the study were manufactured by dispersing the $\mathrm{CuO}$ and $\mathrm{Al}_{2} \mathrm{O}_{3}$ nanoparticles at $0.05 \mathrm{wt} \%$ concentration into water. For dispersion stability, nanofluids with the highest thermal conductivity were selected and added to the surfactant CTAB or AG in various concentrations. All thermal conductivities of the nanofluids were higher than those of water, and it was confirmed that there was a significant difference in thermal conductivity between nanofluids and water. The nanofluids with the highest thermal conductivity were chosen and applied to the PVT system as working fluids. The selected nanofluids were $\mathrm{CuO}+\mathrm{AG}(1 / 2$ times the amount of nanoparticles) and $\mathrm{Al}_{2} \mathrm{O}_{3}+\mathrm{CTAB}(1 / 10$ times the $\mathrm{CMC}$ concentration). The thermal conductivities of $\mathrm{CuO} /$ water and $\mathrm{Al}_{2} \mathrm{O}_{3} /$ water as nanofluids were $0.901 \mathrm{~W} / \mathrm{m} \cdot{ }^{\circ} \mathrm{C}$ and $0.829 \mathrm{~W} / \mathrm{m} \cdot{ }^{\circ} \mathrm{C}$, respectively. The PVT systems using nanofluids showed a significant increase in thermal efficiency compared to the water-based system, but the difference in electrical efficiency was not significant. The $\mathrm{CuO} /$ water and $\mathrm{Al}_{2} \mathrm{O}_{3}$ /water-based PVT systems showed higher efficiency than the water-based system. Thus, the heat transfer was improved by nanofluids with high thermal conductivity. The reason that the difference in electrical efficiency was small was because the reduction of the surface temperature was small, and the area of the PV module used in the study was very small, such that the efficiency of the cell was not greatly changed due to the thermal characteristics of the cell.

Through this study, it was confirmed that the heat transfer characteristics were improved by adding nanoparticles to the base fluid. It was also suggested that application of nanofluids improves system efficiency through increased heat transfer. However, the PVT system, which was fixed in one direction, showed no significant temperature change on the surface of the cell, and the maximum temperature of the heating medium was not high. Therefore, in order to further investigate the effect of nanofluids on the efficiency, research should be conducted on tracking and concentrating of PVT systems in which a high cell temperature could be induced to obtain a high degree of thermal energy, with a reduction of the temperature and an improvement in efficiency.

Author Contributions: All authors conducted this study. J.H.L. wrote and revised this paper. S.G.H. analyzed the data. G.H.L. provided professional guidance and modified this paper.

Funding: This research was supported by the Basic Science Research Program through the National Research Foundation of Korea (NRF) funded by the Ministry of Science, ICT and Future Planning (2017R1A2B4011469).

Conflicts of Interest: The authors declare no conflict of interest.

\section{References}

1. Hosenuzzaman, M.; Rahim, N.A.; Selvaraj, J.; Hasanuzzaman, M.; Malek, A.B.M.A.; Nahar, A. Global prospects, progress, policies, and environmental impact of solar photovoltaic power generation. Renew. Sustain. Energy Rev. 2015, 41, 284-297. [CrossRef]

2. Nahar, A.; Hasanuzzaman, M.; Rahim, N.A.; Parvin, S. Numerical investigation on the effect of different parameters in enhancing heat transfer performance of photovoltaic thermal systems. Renew. Energy 2019, 132, 284-295. [CrossRef]

3. Jia, Y.; Alva, G.; Fang, G. Development and applications of photovoltaic-thermal systems: A review. Renew. Sustain. Energy Rev. 2019, 102, 249-265. [CrossRef] 
4. Charalambous, P.G.; Maidment, G.G.; Kalogirou, S.A.; Yiakoumetti, K. Photovoltaic thermal (PV/T) collectors: A review. Appl. Therm. Eng. 2007, 27, 275-286. [CrossRef]

5. Chow, T.T. A review on photovoltaic/thermal hybrid solar technology. Appl. Energy 2010, 87, 365-379. [CrossRef]

6. Tripanagnostopoulos, Y.; Nousia, T.; Souliotis, M.; Yianoulis, P. Hybrid photovoltaic/thermal solar systems. Sol. Energy 2002, 72, 217-234. [CrossRef]

7. Aste, N.; Leonforte, F.; Del Pero, C. Design, modeling and performance monitoring of a photovoltaic-thermal (PVT) water collector. Sol. Energy 2015, 112, 85-99. [CrossRef]

8. Prakash, J. Transient analysis of a photovoltaic-thermal solar collector for co-generation of electricity and hot air/water. Energy Convers. Manag. 1994, 35, 967-972. [CrossRef]

9. Chow, T.T.; Pei, G.; Fong, K.F.; Lin, Z.; Chan, A.L.S.; Ji, J. Energy and exergy analysis of photovoltaic-thermal collector with and without glass cover. Appl. Energy 2009, 86, 310-316. [CrossRef]

10. Du, B.; Hu, E.; Kolhe, M. Performance analysis of water cooled concentrated photovoltaic (CPV) system. Renew. Sustain. Energy Rev. 2012, 16, 6732-6736. [CrossRef]

11. Sharaf, O.Z.; Orhan, M.F. Concentrated photovoltaic thermal (CPVT) solar collector systems: Part I-Fundamentals, design considerations and current technologies. Renew. Sustain. Energy Rev. 2015, 50, 1500-1565. [CrossRef]

12. Coventry, J.S. Performance of a concentrating photovoltaic/thermal solar collector. Sol. Energy 2005, 78, 211-222. [CrossRef]

13. Kumar, A.; Baredar, P.; Qureshi, U. Historical and recent development of photovoltaic thermal (PVT) technologies. Renew. Sustain. Energy Rev. 2015, 42, 1428-1436. [CrossRef]

14. Dubey, S.; Tay, A.A.O. Testing of two different types of photovoltaic-thermal (PVT) modules with heat flow pattern under tropical climatic conditions. Energy Sustain. Dev. 2013, 17, 1-12. [CrossRef]

15. Imtiaz Hussain, M.; Lee, G.H. Experimental and numerical studies of a U-shaped solar energy collector to track the maximum CPV/T system output by varying the flow rate. Renew. Energy 2015, 76, 735-742. [CrossRef]

16. Bambrook, S.M.; Sproul, A.B. Maximising the energy output of a PVT air system. Sol. Energy 2012, 86, 1857-1871. [CrossRef]

17. Na, M.S.; Hwang, J.Y.; Hwang, S.G.; Lee, J.H.; Lee, G.H. Design and Performance Analysis of Conical Solar Concentrator. J. Biosyst. Eng. 2018, 43, 21-29. [CrossRef]

18. Choi, S.U.S.; Eastman, J.A. Enhancing Thermal Conductivity of Fluids with Nanoparticles; Argonne National Lab.: Lemont, IL, USA, 1995.

19. Lee, S.; Choi, S.U.-S.; Li, S.; Eastman, J.A. Measuring Thermal Conductivity of Fluids Containing Oxide Nanoparticles. J. Heat Transf. 1999, 121, 280-289. [CrossRef]

20. Asirvatham, L.G.; Vishal, N.; Gangatharan, S.K.; Lal, D.M. Experimental Study on Forced Convective Heat Transfer with Low Volume Fraction of CuO/Water Nanofluid. Energies 2009, 2, 97-119. [CrossRef]

21. Nassan, T.H.; Heris, S.Z.; Noie, S.H. A comparison of experimental heat transfer characteristics for $\mathrm{Al}_{2} \mathrm{O}_{3} /$ water and $\mathrm{CuO} /$ water nanofluids in square cross-section duct. Int. Commun. Heat Mass Transf. 2010, 37, 924-928. [CrossRef]

22. Saidur, R.; Leong, K.Y.; Mohammad, H.A. A review on applications and challenges of nanofluids. Renew. Sustain. Energy Rev. 2011, 15, 1646-1668. [CrossRef]

23. Lu, L.; Liu, Z.-H.; Xiao, H.-S. Thermal performance of an open thermosyphon using nanofluids for high-temperature evacuated tubular solar collectors: Part 1: Indoor experiment. Sol. Energy 2011, 85, 379-387. [CrossRef]

24. Kang, W.; Shin, Y.; Cho, H. Economic Analysis of Flat-Plate and U-Tube Solar Collectors Using an $\mathrm{Al}_{2} \mathrm{O}_{3}$ Nanofluid. Energies 2017, 10, 1911. [CrossRef]

25. Karami, N.; Rahimi, M. Heat transfer enhancement in a PV cell using Boehmite nanofluid. Energy Convers. Manag. 2014, 86, 275-285. [CrossRef]

26. Al-Waeli, A.H.A.; Sopian, K.; Chaichan, M.T.; Kazem, H.A.; Hasan, H.A.; Al-Shamani, A.N. An experimental investigation of $\mathrm{SiC}$ nanofluid as a base-fluid for a photovoltaic thermal PV/T system. Energy Convers. Manag. 2017, 142, 547-558. [CrossRef] 
27. Al-Shamani, A.N.; Sopian, K.; Mat, S.; Hasan, H.A.; Abed, A.M.; Ruslan, M.H. Experimental studies of rectangular tube absorber photovoltaic thermal collector with various types of nanofluids under the tropical climate conditions. Energy Convers. Manag. 2016, 124, 528-542. [CrossRef]

28. Godson, L.; Raja, B.; Mohan Lal, D.; Wongwises, S. Enhancement of heat transfer using nanofluids-An overview. Renew. Sustain. Energy Rev. 2010, 14, 629-641. [CrossRef]

29. Li, X.F.; Zhu, D.S.; Wang, X.J.; Wang, N.; Gao, J.W.; Li, H. Thermal conductivity enhancement dependent pH and chemical surfactant for $\mathrm{Cu}-\mathrm{H}_{2} \mathrm{O}$ nanofluids. Thermochim. Acta 2008, 469, 98-103. [CrossRef]

30. AVENTION. 2018. Available online: https://www.avention.co.kr (accessed on 28 July 2019).

31. He, W.; Zhang, Y.; Ji, J. Comparative experiment study on photovoltaic and thermal solar system under natural circulation of water. Appl. Therm. Eng. 2011, 31, 3369-3376. [CrossRef]

32. Huang, B.; Lin, T.; Hung, W.; Sun, F. Performance evaluation of solar photovoltaic/thermal systems. Sol. Energy 2001, 70, 443-448. [CrossRef]

33. Michael, J.J.; Iniyan, S. Performance analysis of a copper sheet laminated photovoltaic thermal collector using copper oxide-Water nanofluid. Sol. Energy 2015, 119, 439-451. [CrossRef]

34. Al-Waeli, A.H.A.; Chaichan, M.T.; Kazem, H.A.; Sopian, K. Comparative study to use nano-( $\mathrm{Al}_{2} \mathrm{O}_{3}, \mathrm{CuO}$, and $\mathrm{SiC}$ ) with water to enhance photovoltaic thermal PV/T collectors. Energy Convers. Manag. 2017, 148, 963-973. [CrossRef]

35. Sardarabadi, M.; Passandideh-Fard, M. Experimental and numerical study of metal-oxides/water nanofluids as coolant in photovoltaic thermal systems (PVT). Sol. Energy Mater. Sol. Cells 2016, 157, 533-542. [CrossRef]

36. Tang, L.Q.; Zhu, Q.Z. Performance Study of Flowing-Over PV/T System with Different Working Fluid. Appl. Mech. Mater. 2014, 488, 1173-1176. [CrossRef]

(C) 2019 by the authors. Licensee MDPI, Basel, Switzerland. This article is an open access article distributed under the terms and conditions of the Creative Commons Attribution (CC BY) license (http://creativecommons.org/licenses/by/4.0/). 